THE CORRUPTION OF CHRISTIANITY THROUGH PAGANISM DURING THE FIRST TWO CENTURIES. 


\title{
THE CORRUPTION OF CHRISTIANITY THROUGH PAGANISM DURING THE FIRST TWO CENTURIES.
}

\author{
BY REv. ABRAM HERBERT LEWIS, D.D., \\ Plainfield, N. J.
}

INTRODUCTORY NOTE.-Desiring to bring this paper within the time assigned for reading, I have condensed it by grouping representative facts, rather than attempt an exhaustive treatise with full quotations and references. (Consult note, p. 86.)

Genuine "Higher Criticism" ought to be applied yet more to the first two centuries of Christian history, to unearth new material, and carefully analyze and classify that which we have. This should be done without polemic intent, and free from the perverting influences of controversy relating to Apostolic Succession, Dogmatic Theology, or Denominational History.

Church History is the record of a world-wide, time-filling, and veritable conflict between right and wrong, God and Satan. This conflict is neither described, explained, nor understood, by tabulating events, or constructing chronology. These are little more than straws, that float on the surface of a stream, compared with the influences which create the stream. History is related to ordinary events, as the life currents throbbing in the veins of the oak are related to the leaves which fringe its branches. These influences do not operate by chance, nor in irregular detachments. History is an organic and organific whole, a living entity, made up of reciprocal causes and effects. These deeper causative currents cannot be understood unless the whole field be surveyed, and the various stages of the conflict be noted and 
compared. This involves the study of the changing methods by which Satan strives to thwart the progress of truth, and the work of man's redemption. Hence successful inquiry concerning the methods by which Christianity was assailed, at first, must be made in the light of the methods which Satan used previous to the time of Christ. This requires a glance at the most revolting facts in the history of pagan religions.

The sun-worship cult is the oldest and the most nearly universal form of paganism. Phallicism, including licentious worship in all its forms, was the lowest phase of that cult. This sanctified lust was the successful weapon which Satan used against God's ancient people. It corrupted the social and religious life of the Israelites more than all other influences. It lured them from loyalty to Jehovah and made them devotees of Baal and Ashtoreth, until the shrines of sanctified lust crowned every hill-top, and nameless symbols were set up in the temple of Jehovah at Jerusalem. The prominent method of warfare pursued by Satan previous to the time of Christ was along the line of man's animal nature; it was sanctified lust; impurity in the name of religion. His aim was not so much to oppose Jehovah worship, openly, as to corrupt it. Christ came when the world was grovelling thus in impurity, groping in the darkness of human philosophy, and moaning in spiritual hunger. His teachings, and the spiritual kingdom which he inaugurated, were far more than a protest against the formalism and the errors of Judaism. The attitude of the world's spiritual battle-field was everywhere changed by his coming. His Gospel revealed the only radical cure for sin, the only safeguard against the evils which had corrupted the pagan world, and so nearly destroyed the Jewish Church.

Fearing that Christ's coming heralded his overthrow, Satan rushed into a personal encounter, eager to defeat, through temptation, him with whom he could not cope in open battle. Vanquished in the wilderness, Satan resumed his former tactics, and sought by indirection that which he could not gain by assault. History shows that Satan's campaign embraced three vital lines of operation: 
(A) The modification or destruction of the authority of the Old Testament, and the perversion of the New.

$(B)$ The corrupting of Christianity by a false standard of Church membership.

(C) The perversion of organized Christianity through union with the state.

In keeping with this policy we find the following facts:

Pagan infuence minimized or destroyed the authority of the Old Testament.

The Christ of the New Testament is the Messiah of the Old. The two dispensations are different methods of administering God's government, but not antagonistic. The Christian dispensation was the spiritual efflorescence of the Jewish. It grew from it as the lily from the bulb. We must therefore look outside of Christianity for the early opposition to Judaism and the Old Testament.

Gnosticism, as an all-embracing term, is the best name for the philosophico-religious influences which gradually undermined the authority of the Hebrew Scriptures and seriously corrupted the New Testament by false interpretation. This use of the term must not be confounded with the more common one, which applies the name Gnostic to certain heretical sects of later times. The system existed long before the name became current; before the time of Christ. It was the product of Oriental Dualism, in the ever-recurring effort to harmonize the conflict between spirit and matter. It mingled with Jewish, Egyptian, and Grecian thought, modifying and being modified by each. Its attitude toward the Hebrew Scriptures was always antagonistic. It taught that the creator of this world, the God of the Jews, and the Author of the Old Testament, was inferior to Christ ; that he could produce nothing which was essentially good; that matter was evil; that all revelation from the God of the Old Testament was imperfect, and ephemeral; that Satan could overcome him; that Christ came to destroy his works, and supersede his kingdom.

Paul was battling Gnostic narrowness, as well as Jewish exclusiveness, when he taught that Jehovah "is the God of the Gentiles also." The recognition of this Gnostic element 
in New Testament history throws much light upon that period, especially upon the Epistles. The opening of the Fourth Gospel cannot be understood, except we see in it the exaltation of Christ, the true LOGOS, in contrast with the logos theories of Gnosticism. The Epistles contain many warnings against this pagan error. Paul was quite as anxious to save his converts from the "lawlessness" of Gnosticism, as from the ceremonialism of the Jews. "The mystery of iniquity," the "Antichrist," of which Paul prophesied, and against which he warned those who were most endangered by it, through Grecian influences, was Gnosticism.

Dr. Schaff describes it most aptly, as follows:

"The opposite extreme is a false Gentile Christianity; which may be called the Paganizing or Gnostic heresy. It is as radical and revolutionary as the other is contracted and reactionary. It violently breaks away from the past, while the Judaizing heresies tenaciously and stubbornly cling to it as permanently binding. It exaggerates the Pauline view of the distinction of Christianity from Judaism, sunders Christianity from its historical basis, resolves the real humanity of the Saviour into a Doketistic illusion, and perverts the freedom of the Gospel into Antinomian licentiousness. The author, or first representative of this baptized heathenism, according to the uniform testimony of Christian antiquity, is Simon Magus, who unquestionably adulterated Christianity with pagan ideas and practices, and gave himself out, in pantheistic style for an emanation of God. Plain traces of this error appear in the later Epistles of Paul to the Colossians, to Timothy, and to Titus, the second Epistle of Peter, the first two Epistles of John, the Epistle of Jude, and the messages of the Apocalypse to the seven churches."- "Church History," vol. i., p. 566; N. Y., 1882 .

Under the prevailing syncretic tendency, Gnosticism permeated all forms of religious thought as by a chemical union. Unhappily it was not an isolated system, with repelling barriers. It prepared the way for the speculative theology of the Greek Fathers, and for the later Gnostic 
sects. Much of the difference between this speculative theology and Gnosticism was in degree, rather than in kind; while Neo-Platonism, compounded from Oriental and Occidental paganism, and rejecting Judaism, was especially fitted to corrupt Christianity. By rejecting or allegorizing the Old Testament, and by allegorizing the New, Gnosticism weakened the only basis for conscience towards God, and removed the only safe ground for practical morality. Its spiritual pride destroyed the consciousness of $\sin$, and its frivolous Antinomianism removed condemnation therefor. This wounded New Testament Christianity in a vital point-the point enunciated by Paul when he said, "Where there is no law there is no sin." The opening chapters of Romans are a bugle-blast against Gnostic Antinomianism, and its consequent wickedness.

The Greek Fathers came to Christianity by way of NeoPlatonism, more than by the New Testament. They accepted it, not as the one and only authoritative system, but as one to be blended with others by liberal syncretism. The Greek language brought Christianity into constant contact with Grecian thought, which was corrupted by countless currents of decaying paganism. The glory of Greece had faded when Christianity was born. Internal corruption had buried civil liberty. Philosophy had fallen to the level of superstition. The higher type of the ancient religion of Greece had yielded to unbelief and low materialism. Vice and immorality abounded among all classes, not least that licentiousness which had its source in the older Phallicism of which we have spoken. Justin Martyr taught that the Old Testament prophesied its own dissolution; that it was imperfect, ephemeral, belonging to the Jews only; that the law did not exist before Moses, and was not binding after Christ; that the decalogue was to be kept only in an accommodative sense; that pagan philosophy contained much truth; that Platonism was closely allied to Christianity, etc. Justin represents the dominant theory-making influences of his own and subsequent times. Gnosticism was a prominent factor in formulating much that has come down to us as Christian doctrine. 


\section{Allegorical Interpretation.}

An equally fundamental error, and one destructive to the Scriptures, was the allegorical method of interpreting them. Theoretically, Gnosticism involved a more spiritual religion than that which was set forth in its popular statements and ceremonies. This deeper knowledge constituted the "Mysteries" which only the "initiated" could understand. The Kabbalists applied this theory by claiming to draw from the Old Testament a hidden meaning which had been handed down as a "secret tradition." The allegorical system of interpretation was developed pre-eminently at Alexandria and Ephesus. Through it the Scriptures were subordinated to the GNOSIs, which each "true Gnostic" claimed for himself. Critical exegesis was rare, or wholly unknown. Misquotation of the text abounded, while the infiltration of pagan philosophy, under the plea of allegory, obscured the truth and subordinated the authority of the divine word. This opened the way and compelled the exaltation of Church authority and tradition over the Bible. The ruin which has followed this result is known to every student of Church history. It alone made possible the Papal theory concerning the Scriptures, and concerning the relation of the historic Church to individual salvation.

\section{Baptism and Church Membership.}

The purposes of Satan were by no means fulfilled when the Old Testament was shorn of authority and the New made subservient to his wishes through allegorizing. Christianity must also be perverted as to its organization and practical development. The New Testament made baptism the prerequisite to Church membership, because it was the outward sign of an inward renewal unto eternal life. Baptism thus guarded the Church against the unworthy, and was the sign of consecration to those who had truly entered the spiritual kingdom of Christ. Satan saw that the battle would go against him if only the truly converted were allowed to enter the visible Church. Paganism furnished abundant 
material for corrupting Christianity by a false standard of Church membership. The pagan water-worship cultus had two phases.

$(A)$ Water as an object of worship.

$(B)$ Water applied in religious ceremony, to produce spiritual cleansing.

Both these phases appear in history until the investigator is lost in the shadows of the pre-historic period.

The limits of this paper permit only a brief summary and a comparison between the pagan cult and the perverted theories which found acceptance in the early Church. The native home of pagan water-worship was probably in the East, though it appears in all quarters and on both continents. The baptism of Egypt was known as the "Waters of Purification." In Egypt and in Peru it was believed that water so used cleansed the soul absolutely, and the person was said to be "regenerated." The water was holy, and the place was known, as it was aiterwards by Christians, as the "Holy Bath." The early Christians called it being " brought anew into the world." The pagans gave a new name at baptism, which custom was afterwards followed by Christians. Among the Greeks the revolting mysteries of Cotys, the Thracian goddess, commenced with a purification, a sort of baptism,

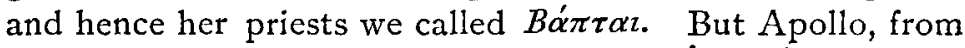
a supposed derivation of his name from $\alpha \pi \circ \lambda \circ v^{\prime} \omega$, was the special god of expiation by baptismal acts. The Thessalians annually celebrated a great festival of cleansing. A work bearing the name of Musæus was a complete ritual of purifications. It distinguished the ceremonies into two orders, $\tau \varepsilon \lambda \varepsilon \tau \alpha i$ and $\varkappa \alpha \theta \alpha \rho \mu o i$. The latter were purifications and expiations accomplished by special sacrifices. The former resembled the purifications performed in the mysteries. The usual mode of purification was dipping into water, or it was performed by aspersion. The baptism of

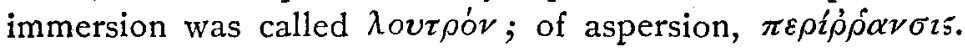
These baptisms were held to have virtue independent of the disposition of the candidate, an opinion which called forth the sneer of Diogenes, when he saw one undergoing bapVol II-6 
tism by aspersion: "Poor wretch," said he, " do you not see that, since the sprinkling cannot repair your grammatical errors, it cannot repair either the faults of your life." Lustral water was placed at the temple doors, and the profane were purified by it, by the priests, before entering. That this is the origin of "Holy Water" in the Romish Church is too well known to need comment. Usually, before entering a temple, the hands and feet were washed. In default of water, sand was used; and salt, as a symbol of incorruption, was regarded as having purifactory virtues. Every impure act demanded purification. In like manner baptism was practised by the Romans, and Juvenal satirizes those who sought to wash away their sins by dipping the head thrice in the water of the Tiber. On the feast of Pallas, the Goddess of Flocks, the shepherds purified themselves by washing their hands thrice in new-fallen dew, or a lustration was effected by aspersion with consecrated water shaken from a branch of laurel or olive.

India has many sacred streams, but the water of the Ganges is thought to have special power to purify. Newborn children are bathed in it, the sick are sprinkled with it, the dead are plunged in it. Drinking of that water washes away $\sin$; therefore the Indians take it with them to their houses, and use it in the ceremonies of their temples. The devout Hindu believes that there is no sin so heinous, no character so black with guilt, but that the waters of the Ganges will cleanse it to snow-like whiteness. This cult is associated with modern Phallicism in India; and at the many Phallic shrines in and around the sacred city of Benares the nameless symbols are deluged with sacred water brought by devout worshippers. In Egypt it was held that the dead were washed from their sins by Osiris in the land of shades; and on the sarcophagi the departed one is often represented kneeling before Osiris, who pours water over him. Among the Scandinavians infant baptism was in vogue long before the introduction of Christianity, and the rite accompanied the naming of the child. Before the performance of this rite the "exposition" of the child was lawful, but after bap. 
tism it was murder. Dipping in water and aspersion with water, or with the blood of a victim, was customary among the Druids, as was also the baptism of fire, probably borrowed by them from the Phœnicians. There are many points where water-worship and sun-worship mingled, as in the lighted torch, used in preparing "Holy Water," a practice which still remains in the Roman Catholic Church. Among the Mexicans, while the new-born child was bathed, the nurse said: "May this bath cleanse thee of the impurity contracted in thy mother's womb ; may it purify thy heart, and procure for thee a good and honorable life. May the unseen God descend upon this water, and free thee from all evil and pollution, and from all ill luck." The pagan faith in water as a cleansing agency arose from the idea that it was permeated by the divine essence, and hence had a supernatural power to remove guilt. With the pagan world trained in such a faith concerning water, such a theory of baptismal regeneration, Satan stood ready to flood New Testament Christianity with this false doctrine, and to fill the Church with baptized pagans.

Turning to the early Fathers, we find fanciful, exuberant, and sometimes contradictory language, but their theories concerning baptism follow the pagan idea that water produces spiritual purity. Forgiveness of sins, imparted righteousness, spiritual illumination, and eternal life come through baptism. They attempt some mingling of New Testament truth by referring to certain passages of Scripture, but genuine exegesis gives no support to their theories. It is not needful that Hermas, Barnabas, and Tertullian be quoted in this connection. Thus it came to pass that great importance was attached to baptism, and elaborate ceremonies, drawn from pagan sources, grew up around it. Among these were preparation, as for the "mysteries": facing westward and eastward; exorcism and consecration of the water; exorcism and insufflation of the candidate; anointing; the sign of the cross; the use of salt; the use of spittle, which was a pagan "charm" against evil; etc. Hence, also, came the practice of delaying baptism until near the close of life, in order to 
make the most of both worlds; and, not least, as a dangerous and persistent corruption, the doctrine of penance to atone for sins committed after baptism. Even the more nearly correct theories of Augustine, in later time, could not overcome these evils, when the Church had become filled with "baptized pagans." Under such theories the masses came to look upon baptism as a sort of magical charm which cleansed from sin, and made the recipient an heir of everlasting life. What is here said is not put forth as a criticism upon the doctrine of "baptismal regeneration," as now held among Protestants, in which the work of Christ is set forth more or less prominently as the ground of regeneration.

Concluding, it is pertinent to say that the most important features of the baptismal question do not appear in the superficial, polemic utterances concerning "modes." These often do little more than show how long men can sail the sea of controversy upon fanciful interpretations, or how far they can float upon the splinter of a Greek accent. But New Testament Christianity was wounded in a vital point when men trained in pagan philosophies became leaders in the Church, and taught baptismal regeneration regardless of the spiritual state of the candidate. The fruit of the error did not develop at once; it increased and ripened for centuries, but it existed in germ and bud, and moulded Western Christianity before the close of the second century. It was the source of the Roman Catholic doctrine of baptism as it now exists.

The two points briefly and imperfectly treated above, have an important relation to the present and future of Christian history. The Protestant movement was the uprising of modern Christianity against the pagan elements as represented in the Roman Catholic Church. The separation from Rome was by no means absolute. The movement has not been uniformly progressive along the line of fundamental differences between New Testament Christianity and the pagan corruptions. Gnostic-born Antinomianism, of ten under the guise of "Christian liberty," yet poisons theology and corrupts practical life. It is now, as always, the foe of sound 
doctrine and good morals. The false idea that baptism, or Church membership through baptism, insures entrance to heaven, yet acts as an upas breath on personal holiness, growth in grace, and devoted service. High standards of duty and action, drawn from the Decalogue as interpreted by Christ, are sadly wanting. Our times need less anxiety about "Apostolic Succession," and conformity to early ceremonies, and a fuller recognition of the voice of Sinai, whose echoes through the centuries demanded answering groans from sacrificial Calvary. Spiritual purity and power cannot abound unless these mountains stand over against each other as God placed them, and as Christ's sacrifice emphasized them. Our times do not need familiarity with the speculative geography of Purgatory, nor the "possible chances" of the unknown future, so much as they need to know that sin is exceeding sinful, and is accompanied by its cxecutioner.

Last July I said to Professor Adolph Harnack: "Will the Protestantism of the next century be more spiritual than now, or less?" He said: "It will be more spiritual, or it will die." I continued: "If it dies, what will be the next scene in Church history?" He answered: "Roman Catholicism will take possession of the world as a new form of paganism."

In the presence of such an answer, from such a man, it is enough to add that Roman Catholicism was germinant in paganized Christianity before the close of the second century. Protestantism has done so little towards the extinction of these errors that the late Roman Catholic Congress at Baltimore declared it a foe no longer to be feared. Be this as it may, the evils and errors which found a place in Christianity before the close of the second century are not wholly eradicated. Though modified by circumstances, they have not lost their essential nature. They are not less dangerous now than when the Holy Spirit condemned them at the lips of the great Apostle to the Gentiles.

There remains only time to name the third element of corruption, spoken of in the opening of this paper. Union of Church and State became operative when the Roman 
Empire took Christianity under its protection, to be governed and regulated, according to the pagan idea which made religion a department of the State. This form of corruption spread rapidly, since the failing Empire fostered Christianity with great eagerness and liberality, hoping to gain new strength, and greater help from the God of the Christians, than it had gained from the gods of its decaying system. This error was positively forbidden by the words of Him who said : "My kingdom is not of this world."

NoTE.-The author of the foregoing essay is aware that brevity makes it unsatisfactory. No two centuries can be separated from history, especially centuries which have left such slight records as those included in the essay. That which precedes, and that which follows, must enter into the consideration of such comparatively unknown years. All who have attempted a critical examination of the period agree that influences outside of Judaism, and of the earliest Christianity, conspired to determine the character of much that is called Christian doctrine. To supplement the brevity of the essay, the author adds a partial list of books which have been examined in gathering the material from which it has been deduced. Every examination should begin with Patristic literature, and with the standard Church histories of all schools. So little has been written upon the specific theme, that a wide range of reading is demanded, if one would reach the ultimate facts. The investigator must also avoid the common error of judging the first two centuries in the light of the nineteenth. It will not do to read the facts of the present, into the history of the past ; neither can we safely supply the gaps in history by our ideas of what ought to have been. First of all, the essayist desires to record his special obligations to Prof. Adolph Harnack, of Berlin, Germany, for the favor of personal consultation concerning the theme of the essay ; and to commend his "Dogmengeschichte" as most valuable in showing the influence of Greek paganism on early Christianity. The greater part of the works named were examined in the British Museum; they are given without chronological arrangement :

J. S. D. Durant: “De Ritibus," Paris, I632. Joseph de Acosta: " Natural and Moral History of India," Madrid, I792, and London, I604. Arnobius: “Adversus Gentes," Clark's Ante-Nicene Library, vol. I9. John Wilson: "India Three Thousand Years Ago," Bombay, 1858. Vans Kenedy: "Researches in Ancient and Hindu Mythology," London, I83I. Charles Daubuz: "Symbolical Dictionary," London, I842. Thomas Taylor: "Baccich and Eleusinian Mysteries," London, I790. S. S. Uvarov: "Essay on the Mysteries of Eleusis," London, 1371. William Hurd: "History of Religious Rites and Ceremonies," Newcastle-on-Tyne, I8II. A. N. Didron: "Christian Iconography," Bohn Library, r849. James Begg: "A Hand-book of Popery," vol. 7 of Fireside Library, I852. (Dean) H. L. Mansel: "The Gnostic Heresies," London, I875. Waltef Blunt: "The English Church and Romish Heresy," London, I843. Max Müller: "Chips from a German Workshop," New York, 
I88I-85. Jacob Bryant: “Analysis of Ancient Mythology," London, 18I7. P. H. Mallet: " Northern Antiquities of the Ancient Scandinavians," London, I847 and 1870. L. Maria Child: The Progress of Religious Ideas," New York, I855. C. C. J. Bunsen : "Egypt's Place in Universal History," London, I848. Charles Coleman: "Mythology of the Hindus," London, I832. Benjamin Thorpe: " Northern Mythology," London, I85x. C. P. Tiele: "Outlines of the History of Religion," London, I877. James Henry Bryant: “The Mutual Influence of Christianity, and the Stoic School," London, I866. Polydore Virgil: "De Inventor Rerum," Venetus, I499. John Poynder: "Popery in Alliance with Heathenism," London, 1835. Cardinal Wiseman: "Letters in Reply to Poynder," , I836. Rev. Thomas Seward: "Conformity between Popery and Paganism," London, I746. Rodolpho Hospinianno: "Festa Christianorum," Tiguri, r6r2 ; also, "De Origine Templorum," Tiguri, I603. Council of Trent: Session 13, Chapter 5. Council of Trent : Session 16. Rev. Joseph Gross: "The Heathen Religion in its Popular Symbolic Development," Boston, 1856. Alexander Hislop: "The Two Babylons," seventh edition, London, I889. Wilson W. Blake: “The Cross, Ancient and Modern," New York, 1888. James Bonwick: "Egyptian Belief and Modern Thought," London, I818. John James Blunt: "Vestiges of Ancient Manners and Customs in Modern Italy and Sicily," London, I823; also, "History of Christian Church, First Three Centuries," London, 1856. Juvenal : "Satires." Pliny: "Natural History." Guilielmo du Choul: "Veterum Romanorum Religio," Amsterdam, I685. Lady Owenson Morgan : "Italy," New York, I821. Livy: "Roman History," Book 23, Chapter 3I ; Book 27, Chapter 4; Book 43, Chapter r3. Dionysius of Malicarnassus: "Roman Antiquities," Book I, Chapters 33 and 55 ; Book 2, Chapters 5, 50, and 73; Book 6, Chapter 45; Book 7, Chapter 72; Book 8, Chapter 72; Spelman's translation, London, 1758 . Didorus: "Siculus," Book I, Chapters $\mathrm{I}$ and 6, London, I700. Edwin Hatch: "The Organization of the Early Christian Church," Bampton Lectures, I880. Smith and Cheathem: "Dictionary of Christian Antiquities," London, I876. Basil Kennett: "Antiquities of Rome," London, I696. Rev. M. Hobart Seymore: "Evenings with the Romanists," London, 1854 ; also, "The Virgin Mary," London, 1869 ; also, "A Pilgrimage to Rome," London, I848. Horace: "Satires," London, I822. Stillingfleet: " Works," vol. 5, London, I7 70 ; also, "Catholics no Idolaters," Worcester, I672. Eusebius: "Life of Constantine," Bohn (Greek Ecc. Hist.), I845. E. D. Pressense : "The Ancient World and Christianity." C. S. Wake: "Serpent Worship," etc., London, I888. S. Baring Gould: "The Origin and Development of Religious Belief," London, I869. Charles Hardwick: "Christ and Other Masters," Cambridge, 1853. George Stanley Faber: " Origin of Pagan Idolatry," London, 1816. Moore: "Hindu Pantheon," London, I8Io. Sir Monier Williams : "Hinduism," London, 1877 ; also, "Brahmanism and Hinduism," London, I887. Joseph Priestly: "A Comparison of the Customs of Moses with Those of the Hindus," Northumberland, I799. Hargrave Jennings: "The Rosicrusians," London, I887. C. W. King: "The Gnostics and Their Remains," second edition, New York and London, I887. H. M. Westroop and C. S. Blake : "Ancient Symbol Worship," London, 1874. Ernest de Bunsen : 


\section{0 \\ The Corruption of Christianity Through Paganism.}

"The Angel Messiah," London, r880; also, " Keys of St. Peter," London, I867. J. Bell : "The New Pantheon," London, 1790. Pierre Mussard : "The Conformity between Modern Thought and Ancient Ceremonies," -__, I745. Council of Trent: "Catechism Concerning the Mass." Bernard Montfaucon : "Antiquities Explained," London, I72 I. Joshua Stopford: "Pagano-Papismus," London, I675. Ovid: " Fasti," Taylor's translation, Liverpool, I839; also, Rose's translation, London, r866. John Landseer: "Sabean Researches," London, I823. Herodotus: "History," Book x, Oxford, I824. John Potter: "Grecian Antiquities," Oxford, I697. Charles Maitland: "The Church in the Catecombs," London, 18 46 . Pausanius: "Description of Greece," London, I794. William Durandus : "Symbolism of Churches and Church Ornaments," London, I843. I, D. Fuss : "Roman Antiquities," Oxford, 1840. Sahagun de Bernardino: "Histo de Neuva Espano" (see Prescott). Prescott: "Conquest of Mexico," Philadelphia, I873. Mourant Brock: "Rome, Pagan, and Papal," London, 1883. Charles Bigg: "The Christian Platonists of Alexandria," New York, 1886. Geo. Smith: "Religion of Ancient Britain," London, I865. Conyers Middleton: "Letters from Rome"-" Works," vol, 3, London, I752 ; also, "A Popish Pagan," London, I743 ; also, " Popery Unmasked," London, I759. Valentinus : "Pistis Sophia," London, 1851. F. D. Maurice: "The Religions of the World, and Their Relations to Christianity," London, I886. Charles Elliott: "Delineations of Roman Catholicism," London, 1851 . Oliver Ormerod: "Pictures of Papists," London, r606. Samuel Johnson: "Julian, Popery, and Paganism," London, I68g. J. W. Draper: "History of the Conflict between Religion and Science," New York, I883. C. F. Dupuis : "Christianity a Form of Solar Myth," London, I873. Geo. Crabb: "Mythology," London, 1877. F. H. Humboldt: "Researches," etc., London, I814. Ernest Renan : "Influence of Rome on Christianity," Hibbert Lectures, London, I88o. John Furniss : "What Every Christian Must Know," London, 1865. Liry: "History," Book 23, translated by Morgan, Dublin, 1850. Plutarch : "Life of Numa," London, I7I3. " Papists no Catholics," Anonymous, London, 1679. Eschines: "Contra Ctesiphion," Oxford, I755. F. C. Baur: "Church History," vol. I, London, 1873. John Potter: "Antiquities of Greece," Edinburgh, 1832. James Cochran: "Protestants' Manual," Edinburgh, 1839. Edwin Hatch: "Growth of Christian Institutions," London, 1887. "Catholic Dictionary," Article, "Mass," London, I884. Andrew Laing: "Myth, Ritual, and Religion," London, I887. R. B. Anderson: "Norse Mythology," Chicago and London, I888. 